\section{COMPRESSED AIR HYGROMETER FOR MEASURING FROST POINT IN THE STRATOSPHERE}

$\mathrm{T}$ H.E most satisfactory method of measuring the water vapour content of air in the stratosphere, where the frost point is $-75^{\circ} \mathrm{C} .\left(-103^{\circ} \mathrm{F}.\right)$ or less, is to determine the frost point with the Dobson-Brewer frost-point hygrometer carried in an aircraft. In this apparatus the water vapour in the air is condensed as ice on the outside of a thimble cooled internally by cold petrol (cooled by a mixture of petrol and solid carbon dioxide) or by liquid air. The observer adjusts the rate of flow of the cooling liquid and notes the termperatures at which the ice deposit increases and decreases. The mean of these two temperatures is taken as the frost point; there may be an interval of 5-10 deg. C. between them. As the frost point is reduced, the ice deposit becomes thin and more difficult to see and, finally, at. frost points below $-85^{\circ}$ C. $\left(-121^{\circ}\right.$ F.) the ice becomes glassy and cannot be seen at all without special optical aid.

Dr. A. W. Brewer (Clarendon Laboratory, Oxford) suggested that the effective range of the instrument could be effectively increased by compressing the incoming air before it reached the hygrometer. Compression raises the frost point, as can be seen from the fact that the humidity mixing-ratio (grams water vapour per kilogram of dry air) is unchanged by the compression. Tho mixing ratio at the low vapour pressures concerned is proportional to $e / p$, where $e$ is the vapour pressure and $p$ the air pressure. The ratio $e / p$ is constant in comprossion so that a ten-fold increase in pressure increases the vapour pressure in the same ratio. This produces an important increase in frost point. Thus, if air with a frost point of $-85^{\circ} \mathrm{C}$. at the pressure of $115 \mathrm{mb}$. prevailing at about $50,000 \mathrm{ft}$. is compressed to $1,014 \mathrm{mb}$, the mean air pressure at sea-level, its vapour pressure is increased from $23.53 \times 10^{-5} \mathrm{mb}$. to $2.0757 \times 10^{-3} \mathrm{mb}$. and its frost point correspondingly increased to $-71.5^{\circ} \mathrm{C}$. $\left(-96 \cdot 7^{\circ} \mathrm{F}.\right)$. A frost point of about $-70^{\circ} \mathrm{C}$. is much more easily measurable than one of $-85^{\circ} \mathrm{C}$.

Mr. P. Goldsmith (Meteorological Research Flight of the Meteorological Office) has proposed (Quart $J$. Roy. Met. Soc., October 1955, p. 607) the use of the engine compressor of a jet aircraft as the source of compressed air. The system has been used on both Ashton and Canberra aircraft, and satisfactory agreement obtained with frost points measured by the normal method. The compressor provides air compressed to a pressure of six to eight times the external air pressure. Goldsmith's article describes in detail the worlsing of the apparatus.

Using this instrument, thirty-five ascents were made from South Farnborough by the Meteorological Research Flight during 1954 to measure frost point in the stratosphere at heights up to $50,000 \mathrm{ft}$. , and the results are given in $\&$ paper by $R$. J. Murgatroyd, P. Goldsmith and W. E. H. Hollings (Quart. J. Roy. Met. Soc., October 1955, p. 533). The compressed air was used above $30,000 \mathrm{ft}$; at lower altitudes there is a danger that the high pressure and temperature of the compressed air would damage the hygrometer. They found the frost point decreased steadily with height through the troposphere and that there was usuaily no change in the rate of fall at the tropopause. In the stratosphere the rate of decrease of frost point decreased with height, and sometimes there was a discontinuity of the rate of fall a few thousand feet above the tropopause. At heights of $10,000 \mathrm{ft}$. to $15,000 \mathrm{ft}$. above the tropopause the frost point became almost constant at a value of $-82^{\circ} \mathrm{C}$. $\left(-115 \cdot 6^{\circ} \mathrm{F}\right.$.) to $-85^{\circ} \mathrm{C}$. The value was the same in summer and winter. The air here is very dry, having a relative humidity with respect to an ice surface of only 1 per cent. The humidity of the stratosphere is important in the study of the flux of long-wave radiation and of the large-scale circulation of the atmosphere. It is believed that such low humidities are only explicable on the supposition that the air has come from the equatorial stratosphere, being warmed ais it does so.

\section{WELDING OF ALUMINIUM AND ITS ALLOYS}

THE welding of many commercial aluminium alloys is rendered difficult as a result of their tendency to crack at temperatures above the solidus, or in other cases at much lower temperatures during the cooling of the weld. In 1944 the light-alloy industry initiated a comprehensive series of researches on this problem at the University of Birmingham, the investigations being started under the supervision of the late Prof. D. Hanson and continued under Prof. L. Aitchison. The Aluminium Developmont Association, in its Research Report No. 27*, has now published a summary of the work of this research team during 1944-50. This quite admirable publication, prepared by Dr. W. I. Pumphrey, a former leader of the team, summarizes the principal investigations and conclusions of the twenty-six papers which have been published.

It was first necessary to develop a hypothesis to explain the high-temperature cracking, and it was shown that on heating to the solidus temperature the ductility fell to zero and the strength dropped rapidly but did not disappear entirely until some higher temperature, still below the liquidus, had been attained. This latter fact was found to be of prime importance, and the temperature above the solidus at which the strength finally disappears emerged as a major factor in the elucidation of the problem.

The development of tests to reveal the suscept. ibility to both high- and low-temperature forms of cracking was essential to the continuation of this work, and such tests, applicable not only to welds but also to castings, have been developed and are described. The low-temperature form of the defect is connected with the ductility of the material and, in particular, with the nature and mode of occurrence of the brittle intermetallic compounds. Where the weld is under conditions of severe restraint, the presence of these compounds in an intercrystalline form is clearly a source of great weakness.

The other main objective of the work was the development of alloys with good welding and mechcnical properties, and three series-the aluminiumcopper-silicon alloys, those of aluminium with zine and magnesium and those with zinc, magnesium and copper-are specifically considered. The tests devised permit the materials to be given at any rate a quasiquantitative value, and, from this, cracking diagrams have been drawn up for a number of binary and * Aluminium Development Association. Research Report No. 27 :
Research into the Welding of Aluminium and its Alloys : a Summary of the Work of the A.D.A. Welding Research Team at the University Pp. 60. (London: Aluminium Development Association, 1955.) 78. 6a. 